\title{
The Green Party: Emerging from the Political Wilderness?
}

\author{
Neil Carter \\ Department of Politics, University of York, Heslington, York YO10 5DD, UK. \\ E-mail:ntc1@york.ac.uk
}

In November 2007, the membership of the Green Party in England and Wales voted overwhelmingly in favour of replacing its collective leadership with a more conventional structure of party leader and deputy leader. This organisational change reflected the increasing electoral focus of the Green Party. Despite a dismal record in UK general elections, the Greens have made some electoral advances in second-order elections in recent years and have slowly moved away from the political margins. But can they overcome the plurality vote electoral system to secure an MP at Westminster? This article examines the electoral record of the Greens, analyses why they have struggled to secure electoral success and assesses their future prospects.

British Politics (2008) 3, 223-240. doi:10.1057/bp.2008.5

Keywords: Green Party; environment; British elections

\section{Introduction ${ }^{1}$}

In November 2007, Green Party members in England and Wales voted overwhelmingly to replace its system of collective leadership with a more conventional leadership structure of Leader and Deputy Leader. ${ }^{2}$ It was a decision that, on the face of it, represented a major compromise of the party's commitment to participatory democracy and its traditional suspicion of the very notion of having a 'party leader'. Will this decision come to be regarded as a significant shift in the direction and, crucially, the electoral fortunes of the Green Party? For although the UK boasts the oldest Green Party in Europe, the Greens have struggled to achieve any significant electoral success and have performed feebly in general elections. However, there have been some modest advances in recent years, with Greens elected to the European Parliament, Greater London Authority (GLA), and a steady increase in local councillors. The Scottish Green Party has been represented in all three Scottish Parliaments, and the Scottish National Party (SNP) was able to form a government in 2007 only with support from the two Green MSPs. More generally, since 2006 public concern about the environment, particularly climate change, has been at the highest level since the peak of interest in 
1989-90 and there has been a sharp intensification in the party politicisation of the environment. Thus the leadership referendum decision came at a time when the Green Party is slowly becoming a more credible electoral force and there has been a resurgence in the electoral salience of the environment. This article examines the electoral record of the British Greens, ${ }^{3}$ analyses why they have struggled to make electoral headway and assesses their future prospects.

\section{Green Party Electoral Performance ${ }^{4}$}

The Green Party's performance in general elections has been mostly dismal (see Table 1). It has failed to get a Green elected to the House of Commons, or even come close to doing so. ${ }^{5}$ Formed in 1973 as 'People', just a handful of candidates contested the two 1974 general elections. It changed its name to the Ecology Party in 1975 and, in order to attract more national publicity, presented a slate of over 50 candidates in the 1979 general election, which secured 5-minute party political broadcasts on radio and television. Between 1979 and 1997, the Green Party's (the name it adopted in 1985) average share of the vote in those seats it contested was between 1.0 and $1.5 \%$, its share of the overall UK votes cast was less than $0.5 \%$ and it lost every deposit. The main development over this period was a steady increase in the number of seats contested, which peaked at 256 in 1992, when the Greens, boosted by impressive performances in the 1989 European Parliament election (see below) and in local council elections, hoped to make a breakthrough in the Westminster election. After failing to do so, the party entered a period of consolidation, putting up only 95 candidates in 1997.

In 2001, with more candidates, the average vote share doubled to $2.9 \%$ and, at last, 10 deposits were saved. The party attracted a record vote of 283,414 in the 2005 general election, representing an average share of $3.4 \%$ in those seats contested and $1 \%$ of the overall vote. Perhaps most significantly, having saved

Table 1 Green Party UK general election performance 1974-2005

\begin{tabular}{lcccc}
\hline & $\begin{array}{c}\text { No. of } \\
\text { candidates }\end{array}$ & $\begin{array}{c}\text { Average \% vote } \\
\text { in seats contested }\end{array}$ & $\begin{array}{c}\text { No. of deposits } \\
\text { saved }\end{array}$ & $\begin{array}{c}\text { Highest \% share } \\
\text { in any seat }\end{array}$ \\
\hline Feb 1974 & 5 & 1.8 & 0 & 3.9 \\
Oct 1974 & 4 & 0.7 & 0 & 0.8 \\
1979 & 53 & 1.5 & 0 & 2.8 \\
1983 & 108 & 1.0 & 0 & 2.9 \\
1987 & 133 & 1.3 & 0 & 1.3 \\
1992 & 256 & 1.3 & 0 & 1.3 \\
1997 & 95 & 1.4 & 0 & 4.3 \\
2001 & 145 & 2.9 & 10 & 9.3 \\
2005 & 203 & 3.4 & 24 & 22.0 \\
\hline
\end{tabular}


a record 24 deposits, there were signs that Greens were building local pockets of support. The best result was in the Brighton Pavilion constituency, where the Green candidate, local councillor Keith Taylor, gained 22\% of the vote to finish third, pushing the Liberal Democrat into fourth place. It was, by a long way, the best ever Green performance in an individual Westminster constituency, and was supplemented by saved deposits in two neighbouring constituencies. Ten of the saved deposits were in London. Elsewhere, they were mostly in urban seats, some with large student populations, including Bath, Bristol South, Leeds West, Norwich South and Sheffield Central. Strong performances in several constituencies in Glasgow and Edinburgh may have been further helped by the presence of seven MSPs (see below).

The Greens have achieved greater success in elections to the European Parliament. After attracting an average share of the vote in 1979 and 1984 that was just slightly higher than for general elections, the Green Party secured an astonishing result in the 1989 election. With candidates contesting all 78 constituencies for the first time, the Greens gained $14.9 \%$ of the vote $(2,292,718$ votes) and saved every deposit. Green candidates polled over $20 \%$ in 17 constituencies, finishing second ahead of Labour in six and ahead of the Social and Liberal Democrat candidates in all but one seat. This result was remarkable both because the Greens had never before attracted even $5 \%$ of the vote in any national election, and because it was at that time the highest share of the vote won by any European Green Party in a national contest (Rootes, 1995a, 69). Yet the plurality voting system then used meant that no Green MEP was elected (Table 2).

The introduction of a regional list system of proportional representation for the 1999 European election was the trigger for the first Green MEPs to be elected. Overall, the Greens averaged $6.3 \%$ of the vote, saving every deposit, and securing just enough in the London (7.7\%) and the south-east $(7.4 \%)$ regions to secure two MEPs, Jean Lambert and Caroline Lucas, respectively. Ironically, the party's highest share of the vote was in the south-west $(8.3 \%)$,

Table 2 Green Party UK European parliament election results 1989-2004

\begin{tabular}{lcc}
\hline & Share of overall vote & MEPs \\
\hline 1979 & $3.7^{\mathrm{a}}$ & 0 \\
1984 & $2.6^{\mathrm{b}}$ & 0 \\
1989 & 14.9 & 0 \\
1994 & 3.2 & 0 \\
1999 & 6.3 & 2 \\
2004 & 6.1 & 2 \\
\hline
\end{tabular}

${ }^{a}$ Average vote for the three candidates.

${ }^{\mathrm{b}}$ Average vote for the seventeen candidates. 
but it was not enough to gain a seat because the south-west elected fewer members than the more populous London and south-east regions. Five years later, the Green performance was almost identical: a national vote share of $6.1 \%$ saw both MEPs re-elected in London (8.4\%) and the south-east $(7.9 \%)$.

Over the last decade, the Greens have also competed with some success in elections to the Scottish Parliament. The first contest in 1999 saw one Green MSP, Robin Harper, elected in the Edinburgh region, but in 2003 the Greens gained $6.8 \%$ of the vote in the eight regional lists to get seven MEPs elected. Four years later, although the Greens appeared to be doing very well in preelection polls, in the event their regional list vote fell to $4.0 \%$ and only two MSPs were elected - in Edinburgh and Glasgow. By contrast, the Greens have had no success in elections to the Welsh Assembly, attracting only 3.5\% in the five regional lists in both 2003 and 2007. In 2007 the Green Party secured its first seat in the Northern Ireland Assembly - just 2 years after the first three councillors were elected in the province. A further product of the Labour Government's constitutional reform programme, the Greater London Assembly, provided another opportunity: three Greens were elected to the 25 person assembly in 2000 with $11.1 \%$ of the top up votes, and two were elected (with 8.4\%) in 2004 .

At the local level, the number of Green party councillors has slowly risen. By the early 1980s, in county and district elections the party was consistently putting up several hundred candidates who attracted roughly $4-6 \%$ of the vote, although several exceeded 10\% in individual wards (Parkin, 1989, 221-229). A handful of candidates were elected and several councillors defected from other parties, so that by 1991 there were 29 Green councillors on different authorities around the country (Rootes, 1995a, 78). Progress remained painfully slow: 10 years later this figure had only increased to 44 (Carter and Rootes, 2001, 104). Subsequently, things have got steadily better: by 2005 there were 69 Green councillors on 30 different authorities (Carter and Rootes, 2006, 477) and in 2007 the party reached triple figures with 110 councillors. Again, it is significant that there are several concentrations of Green councillors: after the 2007 elections, there were 12 Green councillors on Brighton and in Lancaster city councils, and 10 on Norwich and Oxford city councils (www.greenparty. org.uk/news/2991). In recent years, Greens have joined coalition administrations running councils in, inter alia, Castle Morpeth, Lancaster, Leeds and Oxford. In Scotland, after the introduction of a single transferable votes system to local elections, eight Greens were elected in May 2007 - five in Glasgow and three in Edinburgh.

\section{Explaining Green Performance}

The Green Party has failed to achieve the electoral success of its sister parties elsewhere, particularly in the EU15. The comparative analysis of Green Party 
development and electoral performance has identified a number of structural, institutional and political variables that help explain variation between countries (Kitschelt, 1988; Rootes, 1995b; O’Neill, 1997; Müller-Rommel, 1998; Carter, 2007). As it is difficult to detect significant differences in broad structural factors - the degree of economic development, material standards of living, levels of public concern about the environment - between the UK and her neighbours in Northern Europe, it seems sensible to concentrate on the key institutional and political variables, such as the electoral system, the rules governing party funding, federalism, social movement activity and party competition.

\section{Electoral system}

Small parties find it difficult to break into the British plurality voting electoral system because most individual constituency contests are dominated by the major parties. In general elections, people are especially unwilling to 'waste' their votes on a party with little chance of winning a seat. Where a small party can concentrate its vote geographically, as with the Welsh and Scottish nationalists, it has a better chance of gaining representation, but the Greens have been unable to establish any similar regional base.

The significance of the electoral system is underlined by the impact of the introduction of proportional representation in second-order elections, which immediately saw the election of Greens to the European Parliament, the Scottish Parliament and the Greater London Assembly. Suddenly, the Green Party began securing the vote share of between 5 and $10 \%$ that has delivered electoral success to green parties elsewhere in Europe. Other factors may have contributed to these successes. Green parties across the EU have consistently performed better in European elections than in domestic contests, suggesting that voters may regard the environment as an issue that is best dealt with at a supranational level and that the presence of Green MEPs would therefore be desirable. More generally, second-order elections are often treated by the electorate as an opportunity to cast a protest vote for a small party against the government and other established parties, as illustrated by the Green success in the 1989 European Parliament election. It is impossible to disentangle these motivations from the impact of proportional representation, as the latter would probably have encouraged the former. Yet it is clear that the use of proportional representation in these contests greatly benefited the Greens.

Of course, as the Welsh Assembly demonstrates, the presence of proportional representation is no guarantee of green success. Elsewhere, both Norway and Denmark have electoral systems based on proportional representation and electorates with high levels of environmental consciousness and postmaterial values that might appear to provide ideal conditions for green 
parties to flourish, yet they have failed to do so. ${ }^{6}$ However, if the introduction of proportional representation for British general elections is not a sufficient condition for a significant Green breakthrough in the foreseeable future, it is probably a necessary one. ${ }^{7}$

\section{Party funding}

Where countries have generous state funding of parties linked to the achievement of a specific share of the vote, as in Germany, green parties have encountered few financial constraints on contesting elections, operating an effective organisation and even running professional campaigns. The absence of state funding for parties in the UK means that a party with no big financial donors - such as businesses or trade unions - will usually endure a 'hand-tomouth' existence, unable to contest most seats and having little money available to fund professional marketing and campaigning activities. The British electoral rules further discriminate against small parties through the requirement to pay a $£ 500$ deposit for each candidate in a general election, returnable only if a candidate receives $5 \%$ of the vote. Thus, when the Green Party contested 256 constituencies in 1992 general election, the loss of every deposit left it with a huge bill to pay. Indeed, prior to the 1997 general election some Green activists argued that the party should conserve its limited financial resources (for the 1999 European elections). In the event, a much smaller slate of candidates was presented - and again every deposit was forfeited. Despite the subsequent improvement in party fortunes, the Greens still felt able to contest less than a third of seats in the 2005 general election. ${ }^{8}$

\section{Federalism}

Federalism has been identified as contributing positively to Green Party development in, for example, Germany, Austria, Belgium and Switzerland (Müller-Rommel, 1998, 149). The advantage of a federal structure is that the existence of elected state or regional political authorities provides multiple opportunities for emerging parties to articulate their political demands, establish a presence and gain publicity, as a potential stepping stone to national-level success. Until recently, the British unitary state provided few such access points for the Greens and other small parties. However, the Labour Government's extensive programme of constitutional reforms resulted in the creation of new legislatures in Scotland, Wales and Northern Ireland - and London - which have strong echoes of federalism. This quasi-federal structure has undoubtedly benefited the Greens, bringing electoral success, a political presence and even some policy influence. In London, Ken Livingstone has regularly worked with Green members, particularly on environmental issues 
such as the congestion charge. The accession of a minority SNP administration after the 2007 Scottish Parliament election was made possible only by a 'Cooperation Agreement' in which the two Green MSPs voted for SNP leader, Alex Salmond, as first minister in exchange for an agreement to take action against 'climate change pollution' and to oppose the construction of new nuclear power stations. In addition, the SNP supported a Green MSP, Patrick Harvie, as Chair of the Transport, Infrastructure and Climate Change Committee.

\section{Links with new social movements}

In several countries, new social movement activity was an important catalyst for the development of green parties. The broad coalition of environmental and leftist groups that formed the anti-nuclear movements of the 1970s and 1980s was particularly conducive to Green Party formation in Germany, France, Finland and Italy, while the Austrian and Swedish green parties emerged from referendum campaigns against nuclear power (Rootes, 1995b, 237). Consequently, green parties in these countries were rooted in a wider political network and had a large pool of potential supporters. By contrast, as the brainchild of a small discussion circle of concerned conservative environmentalists, the British Green Party had no social movement origins. Nor did it find it easy to build such links subsequently. The Labour Party, at least historically, had a relatively inclusive attitude towards dissident social movements. Consequently, groups such as the Campaign for Nuclear Disarmament were encouraged to focus their efforts on persuading Labour to change its policy rather than building links with a Green Party that was regarded as an irrelevant single-issue political force (Rüdig and Lowe, 1986). Moreover, although Britain boasts a large environmental movement, members of the professional environmental lobby make a virtue of their non-partisan status, believing that it will allow them to exercise greatest influence over the major parties. They have specifically resisted working closely with the Green Party largely out of fear that close association with an outsider party on the political fringe might reduce their access to government or risk alienating their membership, but also because the Greens have been dismissed as irrelevant (and often unreliable). Since the mid-1990s, the Greens have made a concerted effort to build links with contemporary social movements, such as the anti-roads protesters, opponents of airport expansion and anti-GMO protesters. However, unlike in Germany, for example,

not only did workers, unemployed people, ethnic minorities and so on ignore the party, but the very people who were supposed to be 'Other-minded' - the 
New Social Movement activists, New Left people, the educated middle classes - largely abstained from joining the party (Talshir, 2002, 262). ${ }^{9}$

Some individuals heavily involved in direct action campaigns did join the Green Party - and some were elected as councillors - but most, while not actively hostile to the Green Party, were ambivalent about political parties and generally eschewed the conventional political process. Thus, the Green Party has had few natural allies to draw on as it struggled to establish itself as a significant political force.

\section{Party competition}

The state of political or party competition is a critical factor in Green Party development (Kitschelt, 1988; Rootes, 1995b, 241-247). The absence of political opportunities has meant that the focus of environmental politics in the UK has been on the established parties and the environmental lobby, rather than the Green Party. Party competition has left little space for the Greens to occupy and few opportunities for them to exploit the main issue where they might impress - the environment. Historically, the Conservative and Labour parties have proved adept at providing a sufficiently broad church to incorporate a wide range of ideological positions and, in the case of Labour, to be receptive to dissident social movements. During the 1980s and the early 1990s when the Green Party was emerging, the pre-Blair Labour Party had not yet shifted sharply to the political centre, so there was no equivalent vacuum on the left for the Greens to occupy, as was the case, for example, in West Germany.

Nor was the environment a major source of conflict between the parties. The Conservative and Labour parties, at least until recently, have adopted a preference-accommodation strategy aimed at preventing the environment becoming the subject of party competition (Carter, 2006). When environmentalism began to gain wider support during the 1980s, they engaged in a limited process of party politicisation of the environment, which saw them develop a modest range of environmental policies, but made little attempt to compete on the issue. The significance of party competition is illustrated by the 1989 European election, when the Greens won $15 \%$ of the vote. For a brief period, an unusual combination of political opportunities allowed the Green Party to piggy-back on the rapid growth in public concern about the environment through 1988-90 and to benefit from a strong protest vote against the incumbent Conservative government, a continuing distrust of the Labour Party and the weakness of the newly formed Liberal Democrats (Rootes, 1995a). Subsequently, traditional material issues, such as the poll tax and the deepening recession, crowded out the environment, and this window of 
opportunity quickly closed again. The lesson of the 1989 European Parliament election for the Liberal Democrats, when they finished behind the Greens in all but one constituency, was that if the circumstances were right, the Greens could challenge them for the protest vote. Consequently, since 1992 the Liberal Democrats have tried to negate this threat by embracing the environment more fully and more enthusiastically than their rivals, making it a key issue in successive manifestos and election campaigns (Carter, 2006). Consequently, the Greens have faced tough competition for disaffected 'environmental' voters from the Liberal Democrats and from the Scottish and Welsh nationalist parties, who have all made some attempt to appeal to the environmentalist vote.

Two important developments in party competition have opened up new political opportunities for the Greens. First, the Labour Government's programme of constitutional reforms has had an impact on the configuration of party competition - at least beyond Westminster. Both the Greens and UKIP secured the election of MEPs for the first time, while the establishment of the Scottish Parliament ushered in an era of genuine five-party (six party in the 2003-2007 Parliament) politics in a British legislature.

Secondly, there has been a rapid party politicisation of the environment since mid-2006. Several developments contributed to this transformation, notably the growing concern about climate change following the release of the Stern Review on the Economics of Climate Change (Stern, 2006) and the 4th scientific assessment by the Intergovernmental Panel on Climate Change (IPCC, 2007). David Cameron as Conservative leader has also played an important part, and his well-publicised environmental initiatives elicited a positive response from other parties (Carter and Ockwell, 2007, chapter 5).

\section{Summary}

When looking for explanations for the electoral failings of the Green Party, it is hard to get past the plurality voting electoral system as the principal barrier to progress. Notwithstanding the other, not inconsiderable, obstacles, the absence of proportional representation would still represent an almost insuperable barrier to gaining even a small presence at Westminster. Nevertheless, changes in some of these institutional and political factors have opened up new political opportunities that the Greens have been able to exploit. The next section analyses the capacity of the Green Party itself to make the most of these opportunities and assesses its future electoral prospects.

\section{Future Prospects}

What are the electoral prospects for the Greens? What have the Greens done and what can they do to improve their political influence? Green parties 
everywhere have encountered strong pressure to respond to the logic of electoral competition (Kitschelt, 1989, 41) by adjusting party organisation, programmes and strategy to maximise electoral support. This section examines the extent to which the Green Party's electoral ambitions and the wish to be a more effective political force have led to changes in its original principles, in terms of its organisational structure and ideology, and where this leaves its electoral strategy and prospects.

Green parties elsewhere have faced serious tensions between their unconventional 'new politics' organisational structures based on radical principles of grassroots democracy and the pursuit of electoral success. As green parties gained entry to parliament across much of the EU through the $1980 \mathrm{~s}$ and 1990s, and subsequently to government in several European countries, ${ }^{10}$ they reformed or abandoned some participatory democratic mechanisms in favour of more hierarchical, bureaucratic and professional structures characteristic of established parties (Doherty, 2002; Rihoux, 2006). Although their political marginalisation by the electoral system has meant that the Greens have not been subjected to the same intensity of pressure to change as their sister parties elsewhere, nevertheless similar tensions have led to fierce internal conflicts and significant reforms of the party structure.

The Green Party's original organisational structure was firmly based on participatory democratic principles. The party conference was the main decision-making body, with executive power given to a 25-person party council. All members could attend and vote at local and regional meetings, and at national conference. The party had no leaders, initially electing six speakers and three party chairs. Key party posts were rotated, with a maximum of 3 years in any single job. Members could hold one party post at a time (Kemp and Wall, 1990, chapter 2; Burchell, 2002, 109). Even though the main aim through the 1980s was to communicate the green message to the wider public rather than to win elections, tensions over party organisation grew. The first serious attempt to introduce a more centralised party organisation, the MainGreen initiative in 1986, failed (Kemp and Wall, 1990, 29-30; Burchell, 2002, 114), but its core aims - to improve party efficiency, project a better image and provide leadership - mirrored the classic critique of the grassroots model.

The unexpected success in the 1989 European election brought in a flood of new members and generated unrealistic expectations about an imminent electoral breakthrough. It prompted an influential group of leading party members, including Jonathan Porritt, Sara Parkin and Jean Lambert, to launch the Green 2000 initiative with the aim of capitalising on the surge of support for the party by securing representation in the House of Commons by 2000 (or soon thereafter). The rationale for its proposals to centralise the party structure was that the existing organisational structures and rules were 
complex, inefficient and unprofessional, and the lack of leaders with whom the public could identify would hamper the party's electoral progress. Green 2000 was opposed by a decentralist group that preferred locally based campaigning, which was not election-driven. The victory of Green 2000 supporters at the 1991 party conference resulted in the formation of a smaller 10-person national executive committee, a 28 -member regional council to hold the executive committee accountable, a single party chair and two elected principal speakers. The reforms had no discernable impact on the party's disastrous performance at the 1992 general election. The fierce recriminations in the wake of this debacle intensified the internal factionalism, prompting Parkin to resign and Porritt to step down, and within a year Green 2000 had effectively disbanded.

Although the decentralist wing subsequently held the ascendancy, it made no concerted attempt to overthrow the core elements of the reforms bludgeoned through by Green 2000, which largely remain in place today. More importantly, the party too has largely learnt to live at peace with itself. Many of the criticisms of the Green 2000 initiative were about the way its supporters tried to push the reforms through, rather than the reforms themselves (Burchell, 2002, 123; Doherty, 2002, 104). Subsequently, supporters of Green 2000 accepted that imminent parliamentary representation was never on the cards and that a gradualist, local-based strategy was more realistic; conversely, many decentralists acknowledged that the party did need to become more professional and to present a better image of itself to the public (Burchell, 2002, 115).

The introduction of proportional representation for the European Parliament and the new devolved legislatures has acted as a catalyst for a sharper focus on electoral objectives since 1999. Election campaigning has increasingly made use of the small group of relatively high-profile personalities, notably the two MEPs and Darren Johnson (the leader of the Green group on the GLA and Green candidate for Mayor of London in 2004), and local councillors. Perhaps inevitably these successes led to greater electoral ambitions, which prompted an internal party debate about the need for a more conventional leadership structure. During the referendum campaign in Autumn 2007, supporters of the leadership motion argued that it would: (1) enable the party to 'get our message across much more effectively, because people don't relate to abstract ideas, they relate to the people who represent them'; (2) help the party 'to be more easily understood because we will no longer have to constantly explain strange job titles and unfamiliar structures to a confused public'; (3) leaders will have to do more than just talk to the media - they will 'vote on the Executive, take part in collective decision-making and be held accountable'. ${ }^{11}$ It seems that the referendum debate - although lively and with some vocal opposition to the proposal - unfolded in a way that did not generate the kind of conflict associated with the Green 2000 era. Perhaps the generational 
replacement of members means that newer membership cohorts are less committed to the grassroots democratic principles (Rihoux, 2006, 94)? Either way, the large $(73 \%)$ majority in favour of establishing a leadership role indicates that the dominant mood of members is to ensure that the party can exploit every opportunity to maximise its electoral potential and political impact. $^{12}$

In this respect, the ideological divisions that generated internal tensions in the past seem to have dissipated. During the 1990s the ideology of the Green Party shifted from a quite narrow 'ecological' perspective to adopt a wider 'new politics' approach and an increasingly social justice influenced outlook (Talshir, 2002, 251). Broadly speaking, the Green 2000 faction represented the traditional ecological roots of the party, with a dominant policy focus on environment protection and a strong commitment to the familiar slogan that 'Green politics is neither Right nor Left, but in front'. ${ }^{13}$ The demise of Green 2000 and ascendancy of the decentralists, who included a vocal left-wing faction, saw the party adopting a wider political and social agenda, tackling issues like unemployment, homelessness, poverty and public services. This programme went hand-in-hand with the attempts (noted above) to build links with a range of new social movements. By the end of the decade, the Greens were actively embracing a social justice agenda so that they increasingly looked like the kind of new politics Green Party that Kitschelt (1988) describes as 'leftlibertarian'. Crucially, the intensity has disappeared from the rhetorical internal battles over whether or not the party should be 'left-wing'.

Yet, although Green Party may have shifted its outlook, the electorate tends not to regard environmental politics in partisan terms. Table 3 shows that none of the major parties is perceived as obviously better than its rivals on the issue. Despite championing the environment since the early 1990s, the Liberal Democrats have managed to build up only a slender lead over Labour and the Conservatives. Indeed, it is this lack of ownership of the issue by any party that would have given David Cameron the confidence to seize on the environment as an issue that he believed he could exploit to his advantage. Yet, by September 2007, after more than a year of championing the environment,

Table 3 Party with the best policies on protecting the natural environment?

\begin{tabular}{lcccc}
\hline & Conservative & Labour & Liberal Democrats & None/don't know \\
\hline Sept 2003 & 9 & 14 & 18 & 45 \\
Sept 2004 & 7 & 13 & 16 & 47 \\
Sept 2006 & 12 & 12 & 16 & 44 \\
Sept 2007 & 11 & 8 & 22 & 39 \\
\hline
\end{tabular}

Source: MORI http://www.ipsos-mori.com/polls/trends/bpoki-environment.shtml (accessed 1.02.2008). 
Cameron's efforts seemed to have exerted only a limited impact on voter perceptions of how major parties stand on the environment. If anything, the Liberal Democrat lead had strengthened. ${ }^{14}$ Unfortunately, it is difficult to assess how the Green Party performs on this question because polling organisations conflate the figure for respondents stating that the Greens are best on the environment with those declaring 'None/don't know/another party'. It is possible that the large number of responses in this final column may include a significant minority stating that the Greens are best on the environment. Certainly, during the previous peak of concern about the environment in 1989-90, Gallup polls reported the Green Party as best on the environment (King, 2001, 111). This finding may help explain why, until the appearance of Cameron, the two major parties, fearful that any electoral rewards arising from an increased salience for the environment might simply have accrued to the Liberal Democrats or the Greens - the two parties with the most progressive policies - simply avoided competing on the issue.

Despite embracing a broader left-libertarian agenda since the demise of Green 2000, the Greens are not widely regarded by the British electorate or even the media as a radical left-wing party. The common jibe from right-wing European politicians that Greens resemble watermelons because they are 'Green on the outside, red on the inside' has only limited resonance in Britain (or anywhere else now?). Thus in the 1989 European Parliament election when the Greens performed so well, the party drew voters from all three parties (Rüdig and Franklin, 1992, 43). ${ }^{15}$ While it would be wrong to conclude too much from one unusual second-order election 20 years ago when the Greens were a largely unknown entity and still held a predominantly 'ecological' orientation, the limited recent evidence regarding the voting record of Green voters suggests that this finding may still hold true. Surveys of both the 2003 and 2007 Scottish Parliament elections found that those individuals voting Green in the regional list shared their constituency vote among the other parties, although very few voted Conservative (see Table 4). These data should be treated with great caution because of the small sample sizes; indeed, the gaps between, say, Labour and the Liberal Democrats may not be statistically significant. Moreover, the Scottish experience, where disillusioned Labour voters have additional options with the SNP and the Scottish Socialist Party, may not transfer readily south of the border. Nevertheless, it does indicate that the Greens can attract support from across the centre-left political spectrum, which contradicts the common assumption in political circles that the Greens are most likely to attract disillusioned Labour voters (in 2007 the Scottish Greens themselves specifically targeted Labour constituency voters in a bid to persuade them to cast their list vote for the Greens).

These data send out the key message that the Greens have the potential to attract support from several sources, which would seem to vindicate the current 
Table 4 Scottish Parliament elections 2003 and 2007: How Green voters cast their constituency vote

\begin{tabular}{lcccc}
\hline & 2003 No. of respondents & 2003\% & 2007 No. of respondents & 2007\% \\
\hline Conservative & 3 & 5.1 & 5 & 7.0 \\
Labour & 14 & 23.9 & 17 & 22.0 \\
Liberal Democrat & 19 & 31.8 & 29 & 38.2 \\
SNP & 10 & 16.7 & 20 & 25.8 \\
Other & $13^{\mathrm{a}}$ & 22.5 & 5 & 7.0 \\
Total & 59 & 100 & 77 & 100 \\
\hline
\end{tabular}

${ }^{\mathrm{a}}$ Includes Green and Scottish Socialist party voters.

Sources: 2003 date from ScotCen survey; 2007 data from Scottish Election Survey www. scottishelectionstudy.org.uk.

long-term strategy of overcoming the plurality vote system for the House of Commons by slowly building up pockets of strength wherever grassroots activity proves successful.

Indeed, an analysis of the Green performance in the 2005 general election seems to vindicate this strategy with the finding that "where the Green vote increased on its 2001 vote Labour suffered most, but that where the Greens put up a candidate for the first time in 2005, it was the Liberal Democrats who were most affected' (Curtice et al., 2005, 246). It is true that the biggest pockets of Green strength so far have been mostly in Labour-dominated areas, but that may be primarily a conjunctural outcome of Labour having such a large governing majority and - in 2005 - the presence of many disillusioned voters looking for an alternative party to support. The steady growth in the number of Green councillors is concentrated in a handful of towns, such as Brighton, Lancaster, Norwich and Oxford, where the Greens are now a very visible political presence. These pockets of strength suggest that if a foothold is established at local level by effective grassroots activism, it can then be used as a platform to overcome the obstacles posed by the plurality system, building on the presence of local councillors and an observable Green Party influence over local policy. The 2005 general election indicated that the strategy might be having some limited impact. Certainly, some of the strongest Green performances were in constituencies where there were several Greens on the local council and which the party had targeted for several years. In particular, the third place in Brighton Pavilion and the saved deposits in two neighbouring seats, reflected a base of support that had already delivered six seats on Brighton council. Admittedly, the Greens also did well in several seats where they had no significant local presence. Certainly the Greens saved several deposits in seats with large student populations - irrespective of whether or 
not there were local councillors - where their appeal may have been enhanced by their strong opposition to the Iraq war.

The future prospects for this strategy seem reasonably bright, especially as the party seems to be adopting a more instrumental, hard-headed approach to getting an MP elected. Thus, in Brighton Pavilion, its top target seat, Caroline Lucas MEP and Principal Speaker in 2007-08 has been selected as candidate for the next general election, defeating Keith Taylor, who had steadily built up the Green vote by contesting the constituency in two successive elections. Lucas is certainly the party's most high-profile politician and arguably its most effective public performer. Her prospects were improved by the strong Green performance in the 2007 local elections, when it doubled its presence on Brighton council to 12 councillors and gained $30 \%$ of the vote share in the wards making up the Brighton Pavilion constituency. Another top target is Norwich South where in 2007 the Greens secured 10 seats in Norwich Council, coming first in votes cast across the wards making up the Norwich South constituency. A third target seat is Lewisham Deptford, where the high-profile candidate Darren Johnson secured $11.1 \%$ of the vote in 2005 . In all three constituencies the Greens will hope to improve their vote and their placing, while Lucas must have a realistic outside chance of turning third place into victory.

\section{Conclusion}

Greens remain a marginal force in British politics, punished by the iniquity of the plurality voting system — but their electoral fortunes have taken an upward turn since 1999 as a result of the Labour Government's devolution and electoral reform programmes. How far they can continue to make progress depends in large part on institutional and political factors beyond their control, but new political opportunities have arisen due to shifts in the configuration of party competition and the ascent of environmental issues up the political agenda. Important changes in the organisational structure and strategy of the Green Party over the last 15 years, including the recent referendum vote in favour of electing a party leader, have probably placed it in a better position to exploit these opportunities. The Green Party does still look and feel different - and that is probably good among an electorate that is historically more volatile and more critical of the established parties than at any time in the post-war era — but with a leader, a growing number of higherprofile representatives and an increasing presence across a swathe of subnational legislatures and councils, the party is not so different that it frightens voters away.

But the Greens face a dilemma. One option is to continue, as in the 2005 general election campaign, to adopt a broad set of left-libertarian policies 
within which the environment is just one priority area alongside, for example, opposition to the war in Iraq and defending public services and free speech (Carter and Rootes, 2006, 475). The Greens then did best in seats with relatively large numbers of young people, those with degrees, those professing to have no religion and people without access to a car - typically, the young, well-educated professional living in an urban environment (Curtice et al., 2005, 246), a finding supported by evidence (albeit based on a very small sample) from those voting for the Greens in the 2003 Scottish Parliament election (Curtice, 2006, 115-118). It is a voter profile that may well be receptive to a left-libertarian agenda, which, as all three top target seats are currently held by Labour, may prove most effective in attracting disaffected Labour voters.

An alternative strategy is to play up the Greens' image in the eyes of the electorate as a single issue 'ecological' party in order to exploit the resurgence of environmental politics and appeal to voters across the political spectrum. To date, the recent resurgence of interest in the environment has not obviously benefited the Greens. Good results in the 2007 local elections and Northern Ireland Assembly were countered by a marked decline in vote share in the Scottish Parliament election, while support in Wales remained static. Opinion polls since 2004 show no significant change in national support for the Greens, which has generally hovered at around $2-3 \%$ among those respondents naming a preferred party (e.g. MORI: http://www.ipsos-mori.com/polls/trends/votingall-trends.shtml). Yet Cameron's bid for the green vote indicates that Conservative strategists believe that there is a non-partisan environmental vote to be won. Inevitably, Green prospects will be shaped by whether or not the two major parties are prepared to make the environment a central issue at the next election or, as at every previous general election, it disappears off the radar during the election campaign.

Or perhaps the Greens can ride both horses? Either way, as long as the plurality voting system continues to be used for the House of Commons it is hard to fault the current long-term strategy of slowly building up support from the grassroots.

\section{Notes}

1 I would like to thank Brian Doherty and Chris Rootes for their helpful comments on a draft of this article and Rob Johns for supplying survey data on the Scottish Parliamentary elections.

2 Although the new system is not clear cut, members approved a proposal stating that 'There shall be a Leader and Deputy Leader or Co-Leaders of the Green party'; that is, a pair of candidates could stand as joint Co-Leaders instead of Leader and Deputy Leader. The Scottish Green Party, which separated from the Green Party in England and Wales in 1990, retains two 'Co-Convenors'. 
3 Unless stated otherwise, when reference is made in this article to the 'Green Party' or the 'Greens' since 1990, it refers to the Green Party in England and Wales.

4 The data in this section on electoral performance are drawn from a number of sources, but notably Rallings and Thrasher (2007).

5 Cynog Dafis was elected MP for Ceredigion on a joint Plaid Cymru/Green ticket in 1992, although the Greens later withdrew from this local agreement. Dafis remained a Nationalist MP until he resigned his seat in 2000 to become a PC member of the Welsh Assembly.

6 Kitschelt (1988) puts this failure down to party competition. He categorises green parties as 'left-libertarian' political parties, so the emergence of the left-libertarian Socialist Peoples' Parties in both Norway and Denmark in the 1960s left no space for the nascent green parties to occupy in the 1980s.

7 Les Verts managed a breakthrough in the non-proportional French electoral system in 1997, but only because Jospin's Socialists needed allies, and the system of second round voting gave the Greens some bargaining power.

8 Another factor here is that there are not enough local party organisations and active members to give adequate support to a full slate of Green candidates.

9 So did everyone else: after membership peaked at over 18,500 in 1990, it plummeted to 5,500 in 1993 (Evans, 1993) and slipped even lower through the mid-1990s, before staging a limited recovery in recent years.

10 Since 1995 green parties have joined national government coalitions in Belgium, Czech Republic, Finland, France, Germany, Ireland, Italy and Latvia.

11 Extracts taken from a joint letter sent by Caroline Lucas, Darren Johnson and Sian Berry on behalf of the Green Party Yes Campaign.

12 The Green Party website reports that turnout was 'just under $50 \%$ ' of a membership that in 2006 was between 7 and 8,000 (http://www.greenparty.org.uk/news/3249, 30 November 2007).

13 Although there were different strands within Green 2000: for example, Porritt unambiguously represented this narrower ecological inheritance whereas Parkin was more influenced by the broader new left German Green policy package.

14 An ICM poll in March 2007 showed the parties almost neck-and-neck: Conservative 16\%, Labour $14 \%$, Liberal Democrats $14 \%$, but there is no ICM trend data to compare change over time (http://www.icmresearch.co.uk/media-centre-archive.php?month= March\&year=2007).

15 The European Election Study found that $25 \%$ of Green voters in 1989 had voted Conservative in the 1987 general election, 27\% Alliance, 19\% Labour, 7\% Green and 15\% had not voted (Rüdig and Franklin, 1992, 42).

\section{References}

Burchell, J. (2002) The Evolution of Green Politics, London: Earthscan.

Carter, N. (2006) 'Party politicisation of the environment in Britain', Party Politics 12(6): 747-767.

Carter, N. (2007) The Politics of the Environment: Ideas, Activism, Policy, 2nd edn, Cambridge: Cambridge University Press.

Carter, N. and Ockwell, D. (2007) New Labour, New Environment? An Analysis of the Labour Government's Policy on Climate Change and Biodiversity Loss, York: Centre for Ecology, Law and Policy: http://www.york.ac.uk/res/celp/webpages/projects/foe/introduction.htm.

Carter, N. and Rootes, C. (2001) 'One step forward? Greens and the environment in the 2001 British general election', Environmental Politics 10(4): 103-108.

Carter, N. and Rootes, C. (2006) 'The environment and the greens in the 2005 elections in Britain', Environmental Politics 15(3): 473-478. 
Curtice, J. (2006) 'A Chance to Experiment?', in C. Bromley, J. Curtice, D McCrone and A. Park (eds.) Has Devolution Delivered?, Edinburgh: Edinburgh University Press, pp. 109-122.

Curtice, J., Fisher, S. and Steed, M. (2005) 'The Results Analysed', in D. Kavanagh and D. Butler (eds.) The British General Election of 2005, Basingstoke: Palgrave Macmillan, pp. 235-259.

Doherty, B. (2002) Ideas and Actions in the Green Movement, London: Routledge.

Evans, G. (1993) 'Hard times for the British Green Party', Environmental Politics 2(2): 327-333.

Intergovernmental Panel on Climate Change (2007) Climate Change 2007: The Physical Science Basis, 4th Assessment Report, http://www.ipcc.ch/ipccreports/ar4-wg1.htm.

Kemp, P. and Wall, D. (1990) A Green Manifesto for the 1990s, London: Penguin.

King, A. (ed.) (2001) British Political Opinion, London: Politico's.

Kitschelt, H. (1988) 'Left-libertarian parties: explaining innovation in competitive party systems', World Politics 40(2): 194-234.

Kitschelt, H. (1989) The Logics of Party Formation: Ecological Politics in Belgium and West Germany, Ithaca: Cornell University Press.

Müller-Rommel, F. (1998) 'Explaining the electoral success of green parties; a cross-national analysis', Environmental Politics 7(4): 145-154.

O'Neill, M. (1997) Green Politics and Political Change in Contemporary Europe, Aldershot: Ashgate.

Parkin, S. (1989) Green Parties, London: Heretic Books.

Rallings, C. and Thrasher, M. (eds.) (2007) British Electoral Facts, 1832-2006, Aldershot: Ashgate.

Rihoux, B. (2006) 'Governmental participation and the organizational adaptation of green parties: on access, slack, overload and distress', European Journal of Political Research 45: S69-S98.

Rootes, C. (1995a) 'Britain: Greens in a Cold Climate', in D. Richardson and C. Rootes (eds.) The Green Challenge, London: Routledge, pp. 66-90.

Rootes, C. (1995b) 'Environmental Consciousness, Institutional Structures and Political Competition in the Formation and Development of Green Parties', in D. Richardson and C. Rootes (eds.) The Green Challenge, London: Routledge, pp. 232-252.

Rüdig, W. and Franklin, M. (1992) 'Green Prospects: The Future of Green Parties in Britain, France and Germany', in W. Rüdig (ed.) Green Politics Two, Edinburgh: Edinburgh University Press, pp. 37-58.

Rüdig, W. and Lowe, P. (1986) 'The withered "Greening" of British politics: a study of the ecology party', Political Studies 34: 262-284.

Stern, N. (2006) Stern Review on the Economics of Climate Change, London: H.M. Treasury: http:// www.hm-treasury.gov.uk/independent_reviews/stern_review_economics_climate_change/ sternreview_index.cfm.

Talshir, G. (2002) The Political Ideology of Green Parties, Basingstoke: Palgrave. 